\title{
KONSERVASI SUMBER DAYA TAMAN HUTAN RAYA NGURAH RAI SEBAGAI DESTINASI EKOWISATA
}

\author{
Vina Trisha Manurung a, 1, I Nyoman Sunarta ${ }^{\text {a, } 2}$ \\ 1vinamanurung@yahoo.com,2cairns54@yahoo.com \\ a Program Studi S1 Destinasi Pariwisata,Fakultas Pariwisata,Universitas Udayana, Jl. Dr. R. Goris, Denpasar, Bali 80232 Indonesia
}

\begin{abstract}
This study discusses the conservation of Ngurah Rai Forest Park as a nature resources to make it as ecotourism destination. This park has been launched as an area of Ngurah Rai Mangrove Forest Park, so this area has the potential to serve as an ecotourism destination. This study aims to determine the tourism potential that Ngurah Rai Forest Park has and conservation efforts of the government as regulator to keep and maintain the existing of Ngurah Rai Forest Park as one of the ecotourism destination. Data obtained from one of the office in Denpasar that administer the park which is the Unit Pelaksana Teknis (UPT) Ngurah Rai Forest Park, with data collection techniques which are observation, interviews, and literature study. Determination of informant was done by using purposive sampling technique. The data analysis technique used is descriptive qualitative. It can be concluded about Ngurah Rai Forest Park physical potential (natural) which are mangrove forest panorama, approximately 1.400m tracking path, and the existing as a conservation area for mangrove forests and various animals. Ngurah Rai Tahura conservation efforts have been implemented since 1991-present, government in cooperation with the Japan International Cooperation Agency (JICA) make a wide variety of projects such as Mangrove Information Center (MIC) Project that include a construction of a Mangrove Museum that provide informations about the mangrove ecosystem in Indonesia and also in the whole world.
\end{abstract}

Keywords : conservation, forest park , Ngurah Rai , ecotourism

\section{PENDAHULUAN}

Semboyan "Go Green" acapkali ditemukan di berbagai sudut kota, pelajaran di sekolah, surat kabar, internet, acara TV, bahkan di restoran tempat membeli makan sehari-hari. Bahkan jika mengunjungi pusat perbelanjaan, konsumen harus mengeluarkan sejumlah uang lebih untuk membeli tas plastik, hal ini mengedukasikan konsumen untuk membawa tas belanja masing-masing sehingga tidak menambah kuantitas penggunaan plastik. Semboyan ini sebenarnya berangkat dari keadaan lingkungan dan hutan Indonesia yang kian memburuk setiap harinya. Kerusakan hutan di Indonesia, khususnya di Bali semakin menjadi-jadi seiring dengan adanya eksploitasi massal terhadap sumber daya alam yang dimiliki.

Dalam bukunya yang berjudul "The Travel Industry", Gee (1989) mengatakan "as tourism grows and travelers increases, so does the potential for both positive and negative impacts", pernyataan ini menjelaskan bahwa seiring berkembangnya pariwisata, pasti akan timbul dampak baik itu positif maupun negatif. Suatu tempat maupun aktivitas wisata akan berdampak terhadap lingkungan sekitarnya.
Hutan mangrove keberadaannya makin terdesak oleh kebutuhan manusia, sehingga acapkali dibabat sampai punah. Jika hal ini terus berlanjut dan tidak dihentikan, maka akan timbul degradasi lingkungan seperti abrasi, hilangnya satwa atau biota laut maupun tumbuhan yang memerlukan dukungan hutan mangrove sebagai habitatnya. Menurut Direktorat Jendral Rehabilitasi Lahan dan Perhutanan Sosial (RLPS) tahun 1999, luas potensial hutan mangrove di Indonesia tahun 1999 adalah seluas 8,6 juta Ha yang terdiri atas 3,8 juta Ha terdapat di kawasan hutan dan 4,8 juta Ha terdapat di luar kawasan hutan, Sementara itu berdasarkan kondisinya, diperkirakan 1,7 juta $(44,73 \%)$ hutan mangrove di dalam kawasan hutan dan 4,2 juta $\mathrm{Ha}$ $(87,5 \%)$ hutan mangrove di luar kawasan hutan dalam keadaan rusak (Saparinto, 2007).

Konservasi kawasan Hutan Mangrove Ngurah Rai salah satunya telah dilakukan dengan mengubahnya menjadi Taman Hutan Raya (TAHURA) Mangrove Ngurah Rai yang tentunya mendapatkan pemantauan dan pengelolaan langsung dari pemerintah. Selain itu, TAHURA juga erat kaitannya dengan dunia pariwisata, yaitu sebagai salah satu destinasi 
pariwisata alternatif (ekowisata) yang kunjungannya membutuhkan minat khusus, bukan seperti wisata umum.

Dari penjabaran diatas, akan dibahas mengenai potensi wisata yang dimiliki oleh TAHURA Mangrove Ngurah Rai terkait dengan pengembangan ekowisata di Bali dan usaha konservasi yang dilakukan pemerintah untuk menjaga keeksisan TAHURA Mangrove Ngurah Rai sebagai destinasi ekowisata. Adapun tujuan tulisan ini yaitu untuk mengetahui potensi wisata yang dimiliki Taman Hutan Raya Ngurah Rai dan untuk mengetahui usaha konservasi yang dilakukan untuk menjaga dan mempertahankan keeskisan TAHURA Mangrove Ngurah Rai sebagai destinasi ekowisata.

\section{KEPUSTAKAAN}

1. POTENSI OBJEK WISATA. Dalam kepariwisataan, Pendit (1999) menerangkan bahwa potensi wisata adalah berbagai sumber daya yang terdapat di sebuah daerah tertentu yang bisa dikembangkan menjadi atraksi wisata.

\section{KONSERVASI SUMBER DAYA ALAM} DAN LINGKUNGAN HIDUP. Menurut UU No 23 Tahun 1997, definisi konservasi sumberdaya alam adalah pengelolaan sumberdaya alam tak terbaharui untuk menjamin pemanfaatannya secara bijaksana dan sumberdaya yang terbaharui untuk menjamin kesinambungan ketersediaannya dengan tetap memelihara dan meningkatkan kualitas nilai dan keanekaragamannya (Pasal 1 butir 15).

3. TAMAN HUTAN RAYA. Sebagaimana dalam UU No. 5 Tahun 1990 adalah kawasan pelestarian alam untuk tujuan koleksi tumbuhan dan atau satwa yang alami atau buatan, jenis asli dan atau bukan asli, yang dimanfaatkan bagi kepentingan penelitian, ilmu pengetahuan, pendidikan, menunjang budidaya, budaya, pariwisata dan rekreasi.

4. EKOWISATA. Lascurain (1996), mengungkapkan bahwa ekowisata adalah suatu wisata yang tidak hanya sekedar untuk melakukan pengamatan burung, mengendarai kuda, penelusuran jejak di hutan belantara, tetapi telah terkait dengan konsep pelestarian hutan dan penduduk lokal.

\section{Ruang Lingkup}

Ruang lingkup lokasi dalam tulisan ini adalah Taman Hutan Raya Ngurah Rai yang berada di kawasan Suwung Kauh, Denpasar,
Bali, tepatnya di Jalan By Pass Ngurah Rai KM 21. Alasan pemilihan lokasi ini adalah karena TAHURA Ngurah Rai merupakan sebuah destinasi wisata yang menarik apalagi dengan nilai keunikan alamnya, dan berdasarkan kondisi kekiniannya, penting untuk mengetahui lebih lanjut tentang usaha pemerintah dalam mempertahankan destinasi ini di dunia pariwisata Bali.

Ruang lingkup pembahasan dalam tulisan ini adalah potensi fisik yang dimiliki TAHURA Ngurah Rai dalam hubungannya sebagai sebuah destinasi ekowisata. Pembahasan kedua adalah mengenai usaha konservasi untuk mendukung potensi yang dimiliki. Pembahasan ini dibatasi dengan hanya menelaah tentang usaha pemerintah saja.

\section{METODE \\ Teknik Pengumpulan Data}

Untuk memperoleh data yang relevan, akurat, dan mampu menjawab permasalahan secara objektif, maka digunakan metode/teknik pengambilan data yang sesuai, diantaranya observasi, wawancara mendalam, dan studi kepustakaan.

\section{Teknik Analisis Data}

Teknik analisis yang digunakan dalam penelitian ini adalah analisis deskriptif kualitatif. Teknik analisa ini dilakukan pada saat penelitian berlangsung, mulai dari observasi, wawancara mendalam, dengan para informan, kemudian diuraikan dan disusun dalam bentuk uraian yang menggambarkan suatu keadaan, proses maupun peristiwa tertentu yang sifatnya menerangkan. Pada saat melakukan wawancara mendalam, penulis kurang puas akan informasi yang diberikan informan. Maka dari itu, analisis data ini sudah melalui beberapa tahapan, yaitu : pemilahmilahan data antara data yang relevan dengan yang kurang sehingga hasil kesimpulan lebih mudah didapat dan tidak tercipta multitafsir.

\section{Teknik Penentuan Informan}

Penentuan informan dilakukan dengan menggunakan teknik purposive sampling yang dilakukan dengan mengambil orang-orang yang terpilih betul oleh peneliti menurut ciri-ciri spesifik yang dimiliki oleh informan tersebut (Nasution, 2007).

IV. HASIL DAN PEMBAHASAN

A. Potensi Wisata TAHURA Ngurah Rai 
Keindahan dan keunikan alam merupakan modal utama yang dimiliki TAHURA Ngurah Rai yang dapat menarik minat wisatawan untuk berkunjung dan menjadi aset untuk pengembangan industri pariwisata. Daya tarik inti dari potensi yang ada yang merupakan keadaan dan jenis flora dan fauna yang beragam, serta bentang alam. Berdasarkan penelitian yang dilakukan, pesona atau potensi fisik (alam) TAHURA Ngurah Rai yang ditawarkan, diantaranya :

- Panorama Hutan Mangrove

- Jalan Tracking kurang lebih $1.400 \mathrm{~m}$

- Bird Tower

- Shelter

- Aneka satwa : burung, ikan, kepiting, dan biawak.

Panorama hutan mangrove yang tersebar dan tertata dengan rapi dapat dinikmati melewati jalan tracking atau lebih dikenal dengan istilah mangrove trail sambil jalan santai diatas jalur papan kayu sepanjang kurang lebih $1.400 \mathrm{~m}$. Uniknya, panorama ini acapkali digunakan para calon pengantin untuk melakukan foto pre-wedding, karena panoramanya tampak seperti sedang berada di hutan-hutan belantara, tanpa harus kesulitan untuk mencapainya. Bird tower dibangun kurang lebih $400 \mathrm{~m}$ dari pintu masuk. Menara ini terbuat dari susunan kayu-kayu alami, tidak seperti menara biasanya. Saat wisatawan tiba diatas, wisatawan disuguhi dengan pemandangan seantaro hutan mangrove yang sangat indah. Dari atas wisatawan dapat melihat keseluruhan TAHURA Ngurah Rai. Terdapat 5 shelter atau pondok peristirahatan yang dibangun sebagai tempat perisitirahatan wisatawan untuk bersantai sejenak setelah melakukan tracking sambil menikmati keindahan alam dan satwa air.

Dengan berbagai potensi yang dimiliki, tidak salah jika Kawasan Hutan Mangrove Denpasar ini di penghujung tahun 2009 yang lalu dinobatkan sebagai Kawasan Hutan Mangrove Terbaik di Indonesia, bahkan sekawasan Asia (www.antaranews.com). Seiring dengan usaha dan keberhasilan mengembangkan dan melestarikan berbagai potensi yang dimiliki, TAHURA Ngurah Rai acapkali menjadi rujukan studi banding para ahli mancanegara, baik dari Jepang, Jerman, Pilipina, Italia, bahkan Amerika Serikat. Berikut data kunjungan wisatawan ke TAHURA Ngurah Rai

Tabel 1

Data Jumlah Kunjungan Wisatawan Periode 2009-2010

Berdasarkan Asalnya

\begin{tabular}{|c|c|c|c|c|c|c|c|c|}
\hline \multirow{3}{*}{ No } & \multirow{3}{*}{ Bulan } & \multicolumn{4}{|c|}{ Jumlah Kunjungan Wisata } & \multicolumn{2}{|c|}{ Jumlah } & \multirow{3}{*}{ Keperluan } \\
\hline & & \multicolumn{2}{|c|}{ Nusantara } & \multicolumn{2}{|c|}{ Mancanegara } & \multirow[b]{2}{*}{2009} & \multirow[b]{2}{*}{2010} & \\
\hline & & 2009 & 2010 & 2009 & 2010 & & & \\
\hline 1 & Januari & 408 & 745 & 8 & 32 & 416 & 777 & Wisata \\
\hline 2 & Februari & 348 & 564 & 19 & 12 & 367 & 576 & Wisata \\
\hline 3 & Maret & 763 & 692 & 25 & 38 & 788 & 730 & Wisata \\
\hline 4 & April & 693 & 827 & 24 & 41 & 717 & 868 & Wisata \\
\hline 5 & Mei & 668 & 1257 & 11 & 28 & 679 & 1285 & Wisata \\
\hline 6 & Juni & 674 & 1366 & 10 & 42 & 684 & 1408 & Wisata \\
\hline 7 & Juli & 521 & 904 & 32 & 50 & 553 & 954 & Wisata \\
\hline 8 & Agustus & 495 & 1013 & 38 & 33 & 533 & 1046 & Wisata \\
\hline 9 & September & 757 & 1760 & 25 & 28 & 782 & 1788 & Wisata \\
\hline 10 & Oktober & 708 & 1219 & 8 & 25 & 716 & 1244 & Wisata \\
\hline 11 & November & 471 & 1142 & 11 & 32 & 482 & 1174 & Wisata \\
\hline 12 & Desember & 325 & 1292 & 12 & 16 & 337 & 1308 & Wisata \\
\hline & Jumlah & 6831 & 12781 & 223 & 377 & 7054 & 13158 & \\
\hline
\end{tabular}




\section{B. Usaha Konservasi TAHURA Ngurah Rai Sebagai Destinasi Ekowisata oleh Pemerintah}

Pemerintah telah banyak melakukan perjanjian kerjasama untuk waktu yang cukup panjang (semua data yang tertuang selanjutnya merupakan data resmi dari Departemen Kehutanan). Dalam penyelenggaraan usaha konservasi hutan mangrove, Direktorat Jenderal Bina Pengelolaan Daerah Aliran Sungai dan Perhutanan Sosial (BPDASPS) dan Japan International Cooperation Agency (JICA) telah menandatangi kesepakatan kerjasama proyek yang berjudul The Project on Mangrove Ecosystem Conservation and Sustainable Use (MECS) in the ASEAN Region, pada bulan Maret 2011. Kerjasama yang telah berlangsung selama 3 tahun (s.d bulan Juni 2014) ini merupakan lanjutan dari rangkaian kerjasama yang telah dilakukan JICA dengan Kementerian Kehutanan. Kerjasama yang pertama dilakukan tahun 1991-1999, dengan proyek yang berjudul Development of Sustainable Mangrove Management Project. Hasil dari proyek ini adalah manual silviculture, nursery, mangrove handbook, dan model pengelolaan mangrove yang berkelanjutan. Setelah itu kerjasama dilanjutkan dengan proyek Mangrove Information Center (MIC) Project semenjak bulan Mei 2001-Mei 2004 dengan perpanjangan selama 2 tahun (s.d Mei 2006). Output yang didapatkan melalui proyek ini adalah Gedung Mangrove Information Center yang berlokasi di Bali, didalamnya terdapat museum mangrove dan informasi mengenai ekosistem mangrove di Indonesia dan juga di seluruh dunia .

Selain itu juga terdapat beberapa training program atau program pelatihan yang sampai saat ini masih dijalankan oleh MIC masih dipergunakan untuk kepentingan peningkatan SDM di bidang konservasi hutan mangrove. Kerjasama tahap berikutnya dimulai dari Januari 2007 sampai dengan Januari 2010 dengan project berjudul Sub Sectoral Program on Mangrove Project. Dari proyek ini dihasilkan panduan untuk pembentukan model area pengelolaan mangrove yang berkelanjutan. Mangrove Ecosystem Conservation and Sustainable Use in the ASEAN Region adalah lanjutan dari rangkaian kerjasama sebelumnya, yang bertujuan untuk membentuk mekanisme share-learning, sebuah pembelajaran mengenai konservasi mangrove dan pemanfaatan yang berkelanjutan di negara-negara ASEAN.

Sejak tahun 1992, kawasan TAHURA Ngurah Rai dibuka sebagai kawasan ekowisata yang menawarkan program-program diantaranya : Program Mangrove Education Tour \& Tracking, Program Bird Watching, Program Mangrove Tree Plantation or Adoption, Program Fishing, Program Boating dan Program Canoeing.

Berangkat dari konsep Bali Clean and Green, Gubernur Bali, Made Mangku Pastika, didampingi Ny. Ayu Pastika bersama pada jajaran SKPD di lingkungan Pemerintah Provinsi Bali pada tanggal 23 November 2012, melakukan gerakan penanaman 1000 pohon mangrove di kawasan TAHURA Ngurah Rai. Program penanaman pohon mangrove dapat dilakukan oleh setiap kalangan baik itu masyarakat secara perorangan, kelompok, institusi, lembaga swadaya masyarakat, bahkan lembaga pemerintahan. Langkah pertama yang dapat dilakukan adalah mengajukan proposal ke UPT Tahura Ngurah Rai. Lalu UPT akan mengeluarkan surat ijin, memberikan arahan sekaligus menunjukkan lokasi-lokasi mana yang memang selayaknya dilakukan penanaman kembali.

Usaha konservasi yang telah dilakukan oleh UPT Tahura Ngurah Rai dan MIC adalah pengawasan lingkungan hutan mangrove. Usaha ini diimplementasikan dalam pembentukan Satuan Petugas (satgas) untuk melakukan patroli khusus setiap dua hari sekali, siang dan malam. Pengawasan ini dilakukan untuk mengantisipasi terjadinya pelanggaranpelanggaran lingkungan yang tidak diinginkan. Seperti penanaman, pembababatan, maupun alih fungsi lahan secara ilegal, dan penyalahgunaan fasilitas yang disediakan bagi wisatawan.

Berangkat dari konsep ekowisata yang dinyatakan oleh Lascurain (1996), TAHURA Ngurah Rai telah memenuhi karakteristik sebuah destinasi (bisnis) ekowisata, diantaranya :

1. 1. Menggunakan teknik-teknik ramah lingkungan dan berdampak rendah

2. Mendukung upaya-upaya konservasi

3. 3. Menyadari bahwa alam dan budaya, pengetahuan tradisional merupakan elemen utama untuk pengalaman wisatawan 
4. Memiliki nilai edukasi bagi wisatawan

5. Memilik pemandu/interpreter yang memahami pengetahuan alam dan budaya masyarakat setempat

6. Memberdayakan lingkungan dengan memastikan bahwa flora dan fauna di destinasi tidak terancam keberlangsungan hidupnya

Namun dalam kenyataannya, TAHURA Ngurah Rai belum memberdayakan masyarakat lokal dalam pengelolaan maupun pemanfaatan TAHURA. Usaha konservasi berbasis ekowisata sudah memenuhi karakteristik didalamnya namun masyakat kurang terlibat. Hal ini dapat membawa dampak negatif, karena masyarakat yang kurang dilibatkan, cenderung akan merasa terasing dan malah merusak TAHURA karena mereka tidak merasa terbebani untuk melakukan pelestarian dan perawatan di lingkungan tersebut. Maka dari itu, perlu dilakukan peninjauan ulang terhadap pelaksanaan prinsip ekowisata di TAHURA Ngurah Rai, sehingga bukan hanya pemerintah saja yang memberikan koordinasi, namun masyarakat lokal juga memiliki kuasa untuk beropini dan bersama mengembangkan TAHURA Ngurah Rai.

\section{KESIMPULAN DAN SARAN}

Potensi wisata yang dimiliki TAHURA Mangrove Ngurah Rai lebih mengarah ke potensi fisik. Potensi fisik (alam) TAHURA Ngurah Rai yang ditawarkan, diantaranya panorama Hutan Mangrove, jalan Tracking kurang lebih $1.400 \mathrm{~m}$, bird tower, shelter, dan kawasan konservasi bagi hutan bakau dan aneka satwa : burung, ikan, kepiting, dan biawak. Potensi eksisting wisata inilah yang mendukung diadakannya kegiatan pariwisata alternatif ekowisata yang berwawasan lingkungan dengan mengutamakan keadaan alam, pemberdayaan masyarakat lokal, sekaligus menonjolkan sisi edukasi bagi para wisatawan.

Usaha konservasi TAHURA Ngurah Rai dalam menjaga keeksisannya sebagai destinasi ekowisata telah dijalankan pemerintah semenjak 1991 hingga sekarang dengan kerjasama bersama Japan International Cooperation Agency (JICA) dengan proyek yang berjudul Development of Sustainable Mangrove Management Project. Setelah itu dilanjutkan dengan Mangrove Information Center (MIC)
Project yang didalamnya terdapat pembangunan museum mangrove beserta informasi mengenai ekosistem mangrove $\mathrm{di}$ Indonesia dan juga di seluruh dunia; program pelatihan yang dipergunakan untuk kepentingan peningkatan SDM di bidang konservasi hutan mangrove. Pada 23 November 2012, dilakukan gerakan penanaman 1000 pohon mangrove di kawasan ini. Pengawasan lingkungan hutan mangrove dengan membentuk satgas pun dilakukan untuk mengantisipasi terjadinya pelanggaranpelanggaran lingkungan yang tidak diinginkan.

\section{DAFTAR PUSTAKA}

Anonimous. 1990. Undang-Undang RI Nomor 5 Tahun 1990 tentang Konservasi Sumber Daya Alam Hayati dan Ekosistemnya

Anonimous. 1997. Undang-Undang RI Nomor 23 Tahun 1997 tentang Pengelolaan Lingkungan Hidup.

Ceballos-Lascurain H. 1996. Tourism, Ecotourism and Protected Areas. Cambridge:The World Conservation Union.

Gee, C. Y., et al., (1989). The Travel Industry. New York: Van Nostrand Reinhold.

http://www.dephut.go.id/index.php/news/details/8660

Nyoman S. Pendit. 1999. Wisata Konvensi. Jakarta: Gramedia Pustaka Utama.

Nasution, S. 2007. Metode Research. Jakarta: Bumi Aksara

Saparinto C, 2007. Pendayagunaan Ekosistem Mangrove. Edisi Pertama, Cetakan Kesatu. Semarang:Dahara Prize. 